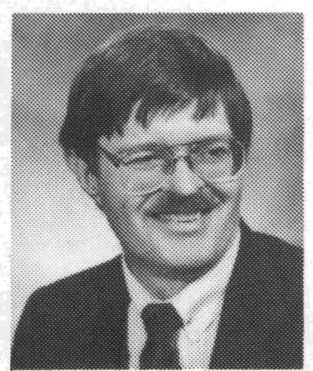

Editorial

H. J. Caulfield, Editor

Of Past and Future-

My Last Editorial

\section{Of the Past}

To John Conant for six hard years of behind-the-scenes work, and

To his staff (Barbara DeNapoli, Ann Lear, Ruth Azevedo, and Irene Breen) for supporting him;

To two successive managing editors (Marybeth Manning and Eric Pepper), who maintained the high standards of quality set by their predecessor, Elaine Cherry, Director of Publications for the Society;

To my predecessor, John DeVelis, for continued encouragement;

To my friend, Joe Yaver, Executive Director of SPIE, for his unfailing support;

To Aerodyne Research, Inc., and especially to Chuck Kolb and Jim Draper, for six years of support not necessarily visible to anyone but me;

To Joe Horner and Winn Gaynor for making "SPIE Reports" exciting and valuable;

To the best executive secretary I have ever known, Shirley Fedukowski, for trying so valiantly to keep me organized;

To the many contributors, special issue editors, reviewers, and readers of Optical Engineering-

Thank you. I have truly appreciated your help.

\section{Of the Future}

To Jack Gaskill, who begins his term as editor on July 1;

To the staff, officers, and governors of SPIE;

To my present employer (Aerodyne Research, Inc.) and my employer as of mid-May (The University of Alabama in Huntsville)-

May our future joint activities on behalf of Optical Engineering be fruitful and exciting.

\section{OPTICAL ENGINEERING EDITORIAL SCHEDULE}

July/August 1985

Holographic Interferometry

Ryszard Pryputniewicz

Worcester Polytechnic Institute

Dept. of Mechanical Engineering

Worcester, MA 01609

$617 / 793-5536$

Nonlinear Optical Materials, Devices, and Applications

Mario Dagenais

GTE Laboratories, Inc.

40 Sylvan Road

Waltham, MA 02254

$617 / 466-4280$

Robert J. Seymour

GTE Laboratories, Inc. 40 Sylvan Road

Waltham, MA 02254

617/466-4202

September/October 1985

\section{Holography}

Lloyd Huff

University of Dayton Research Institute

300 College Park

Dayton, OH 45469

513/229-2113

\section{November/December 1985}

\section{Optical Inspection}

Donald Sweeney

Sandia National Labs.

MS ORG8354

Livermore, CA 94550

415/422-3138

Timothy C. Strand

IBM Research Lab.

K46/282

5600 Cottle Rd.

San Jose, CA 95193

408/284-8919

\section{Spectral Pattern Recognition}

O. I. Sindoni

USAMCCOM, CRDC,

Research Directorate, Physics Div.

SMCCR-RSP-B, Bldg. E5951

Aberdeen Proving Ground, MD 21010

301/671-4256

\section{January 1986}

\section{Optical Computing}

Raymond Arrathoon

Wayne State University

Dept. of Electrical \& Computer Eng.

$701 \mathrm{~W}$. Warren

Detroit, MI

313/577-3738

\section{February 1986}

Materials and Devices for Optical Information Processing

Cardinal Warde Uzi Efron

M.I.T.

Room 13-3134

Cambridge, MA 02139

$617 / 253-6858$

Hughes Research Labs. M.S. RL69

3011 Malibu Canyon Rd. Malibu, CA 90265

213/317-5214 